\title{
The Role of Protein SUMOylation in Human Hepatocellular Carcinoma: A Potential Target of New Drug Discovery and Development
}

\author{
Hongchao Yuan (D), Yuanjun Lu, Yau-Tuen Chan, Cheng Zhang, Ning Wang * and Yibin Feng *(D)
}

Citation: Yuan, H.; Lu, Y.; Chan, Y.-T.; Zhang, C.; Wang, N.; Feng, Y. The Role of Protein SUMOylation in Human Hepatocellular Carcinoma: A Potential Target of New Drug Discovery and Development. Cancers 2021, 13, 5700. https://doi.org/ $10.3390 /$ cancers 13225700

Academic Editor: Cédric Coulouarn

Received: 19 October 2021

Accepted: 12 November 2021

Published: 14 November 2021

Publisher's Note: MDPI stays neutral with regard to jurisdictional claims in published maps and institutional affiliations.

Copyright: (c) 2021 by the authors. Licensee MDPI, Basel, Switzerland. This article is an open access article distributed under the terms and conditions of the Creative Commons Attribution (CC BY) license (https:/ / creativecommons.org/licenses/by/ $4.0 /)$.
School of Chinese Medicine, The University of Hong Kong, 10 Sassoon Road, Pokfulam, Hong Kong, China; hcyuan@hku.hk (H.Y.); yjlu@connect.hku.hk (Y.L.); ecyt@connect.hku.hk (Y.-T.C.); zttc@connect.hku.hk (C.Z.)

* Correspondence: ckwang@hku.hk (N.W.); yfeng@hku.hk (Y.F.)

Simple Summary: The small ubiquitin-like modifier is a highly conserved post-translational modification protein, mainly found in eukaryotes. Recently, studies have shown that SUMOylation promotes the development of liver cancer. This article summarises the recent literature on SUMOylation and Hepatocellular carcinoma (HCC). The mechanism of SUMOs in liver cancer cells was described. It also shows the potential of SUMO as a therapeutic target for liver cancer. At the same time, this article also enumerates the practical application in clinical, developing progress and future direction of HCC in clinical practice.

\begin{abstract}
Small ubiquitin-like modifier (SUMO) is a highly conserved post-translational modification protein, mainly found in eukaryotes. They are widely expressed in different tissues, including the liver. As an essential post-translational modification, SUMOylation is involved in many necessary regulations in cells. It plays a vital role in DNA repair, transcription regulation, protein stability and cell cycle progression. Increasing shreds of evidence show that SUMOylation is closely related to Hepatocellular carcinoma (HCC). The high expression of SUMOs in the inflammatory hepatic tissue may lead to the carcinogenesis of HCC. At the same time, SUMOs will upregulate the proliferation and survival of HCC, migration, invasion and metastasis of HCC, tumour microenvironment as well as drug resistance. This study reviewed the role of SUMOylation in liver cancer. In addition, it also discussed natural compounds that modulate SUMO and target SUMO drugs in clinical trials. Considering the critical role of SUMO protein in the occurrence of HCC, the drug regulation of SUMOylation may become a potential target for treatment, prognostic monitoring and adjuvant chemotherapy of HCC.
\end{abstract}

Keywords: hepatocellular carcinoma (HCC); post-translational modification; SUMOylation; cancer metastasis; cancer drug resistance

\section{Introduction}

Hepatocellular carcinoma (HCC) is the most common primary liver cancer. As of 2020, HCC is the sixth most common cancer globally and the second leading cause of cancer-related deaths [1]. In the past few decades, the incidence of HCC-related deaths has increased. Globally, it is estimated that more than 90,000 new cases of HCC and more than 20,000 deaths related to HCC in 2020 [2]. The prognosis of hepatocellular carcinoma is poor, with a 3-year survival rate of around 16.6\% [3]. Currently, only surgical resection and liver transplant resection are considered as potential cures for HCC. Sorafenib is the first tyrosine kinase inhibitor (TKI) approved by the FDA for the treatment of unresectable HCC. In the ten years before lenvatinib, sorafenib has been the main treatment for HCC [4]. Subsequently, Tyrosine Kinase Inhibitors (TKIs) drugs such as regorafenib, rammucirumab and cabozantinib have successively succeeded in clinical trials. The advent of these TKIs has brought a new approach to the second-line treatment of HCC. At the same time, immune 
checkpoint inhibitors (ICIs), combined immunotherapy and other influential treatment methods have also been introduced [5]. These drugs increase the options available to patients and improve the survival rate of HCC patients [6].

Similar to the ubiquitination pathway, SUMOylation is a post-translational modification process and plays a vital role in many cellular processes. Post-translational modification (PTM), referred to as the covalent and generally enzymatic modification of protein after protein biosynthesis, has been considered to play a definitive role in HCC progression and therapeutic treatments [7]. PTM is a vital cell signal transduction method. The ribosome translates mRNA into a polypeptide chain and forms a mature protein through PTM [8]. This process can introduce new functional groups, such as phosphate. Phosphorylation is the most common post-translational modification and a common mechanism for regulating enzyme activity [9]. Other post-translational modifications include glycosylation, lipidation ... [10]. SUMOylation, as well as other PTMs, can change the properties of the target protein, including but not limited to their activity, positioning, stability and interaction with other proteins [11-16]. Therefore, the imbalance of PTMs can lead to various diseases [17-20].

The protein members of the SUMO family are covalently linked to the lysine residues of the specific target protein through an enzymatic cascade [21]. SUMOylation can either enhance the interaction of modified protein molecules by adding an interaction surface or mask the molecular interactions of the modified target protein. The target protein determines the specific consequences, which depends on the location, stability changes and activity of the target protein [22]. Abnormal SUMOylation modification of target protein is associated with many cancers including colorectal cancer, cervical adenocarcinoma and cervical adenosquamous carcinoma [23]. Blocking the SUMOylation of the target protein can inhibit the progress of cancer cells and stimulate interferon signal transduction, thereby further enhancing the tumour immune response of the subject [24]. A growing body of recent evidence has revealed that SUMOs-mediated SUMOylation was involved in multiple processes of HCC. Figure $1[25,26]$ below is two examples that describe how SUMOylation affects the progress of HCC. Protein SUMOylation has been shown to regulate the cellular process related to cell proliferation and survival, migration and invasion and drug resistance of HCC. In this review, we summarised the recent research inputs of SUMO protein in HCC. Based on the current understanding, we discussed and envisioned the potential of clinical applications of HCC treatment acting on SUMOs. We hope that our article will help the identification of SUMOs targets.

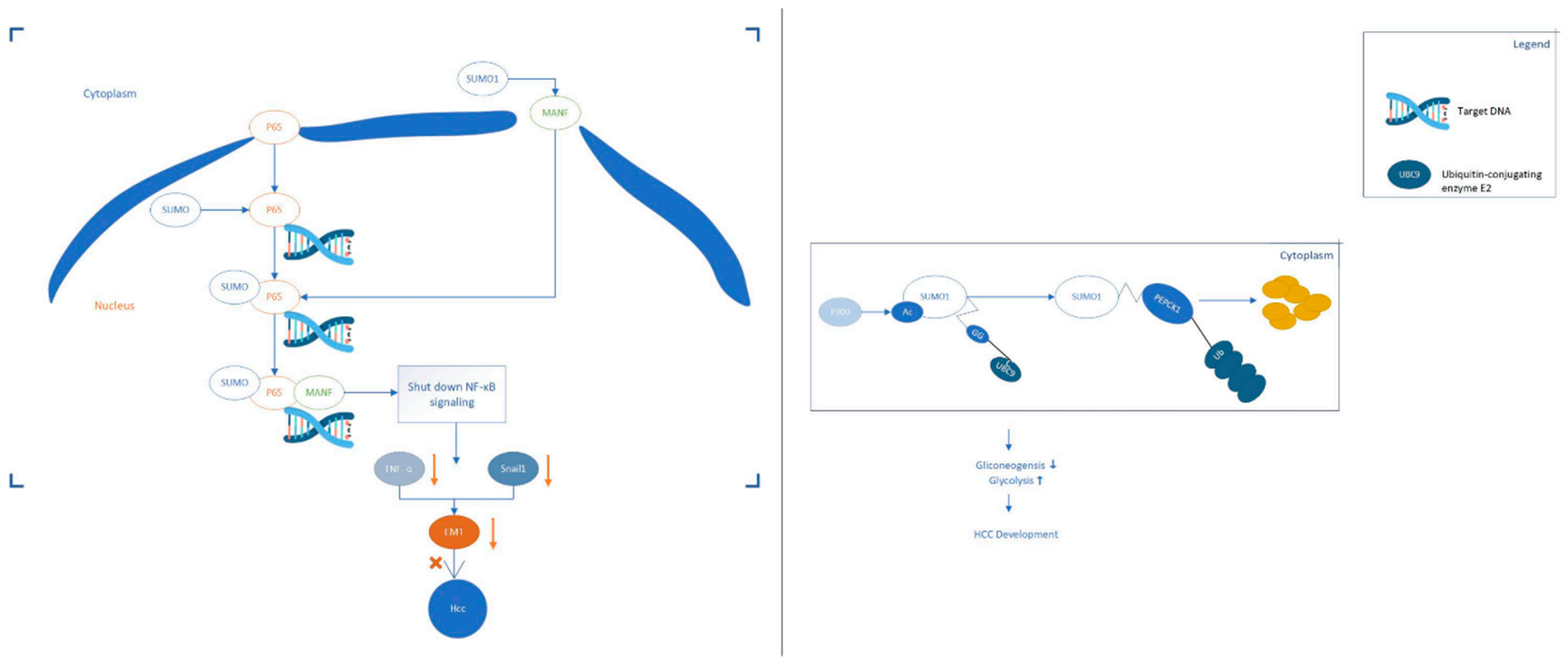

Figure 1. Two examples of SUMO proteins affecting the development process of HCC. (Left): SUMO1 binds to MANF and promotes the transfer of MANF to the nucleus. The SUMOylation of P65 can up-regulate the combination of P65 and MANF to form a repressor complex, thereby hindering the transmission of NF- $\mathrm{kB}$ signals. Eventually, the expression of TNF- $\alpha$ and Snails downstream of the NF-kB signalling pathway is down-regulated, which hinders the progress of HCC. (Right): The 
expression of acetylase p300 in liver cancer is up-regulated and p300-mediated acetylation of Ubc9 can enhance its binding to PEPCK1. Increase the SUMOylation level of PEPCK1. Promote the degradation of PEPCK1, thereby accelerating the proliferation of liver cancer cells.

\section{The Dynamics of SUMOylation in HCC}

SUMOs are a highly conserved protein family with a molecular weight of approximately $12 \mathrm{kDa}$ that plays an essential role in the survival of eukaryote cells [27]. They share similarities with ubiquitin in structure and the C-terminal glycine (Gly) residue involved in the reaction [28]. Most of the SUMOs proteins contain a short consensus sequence $\Psi K X E$, where $\Psi$ represents a large hydrophobic amino acid, $\mathrm{K}$ stands for lysine, $X$ represents any amino acid residue and E represents glutamic acid [21]. SUMOylation is highly dynamic and its cyclical process is shown in Figure 2 [29]. SUMOylation is one of the post-translational protein modification processes that is widely involved in regulating various aspects of protein and cellular activities. SUMOylation mainly regulates the interaction and positioning of the proteins [30]. Current research has found that more than one hundred proteins can serve as the substrate of the cellular SUMOylation process, most of which are nuclear proteins. A few foreign proteins can also be SUMOlated [31]. The main biological functions of SUMOylation modification include regulation of transcriptional activity, regulation mediated by promyelocytic leukaemia nuclear bodies(PML-NBs), the maintenance of the integrity of the genome by regulating the aggregation and separation of chromosomes, the process of DNA repair, regulation of protein stability and nuclear mass transportation, etc. [22].

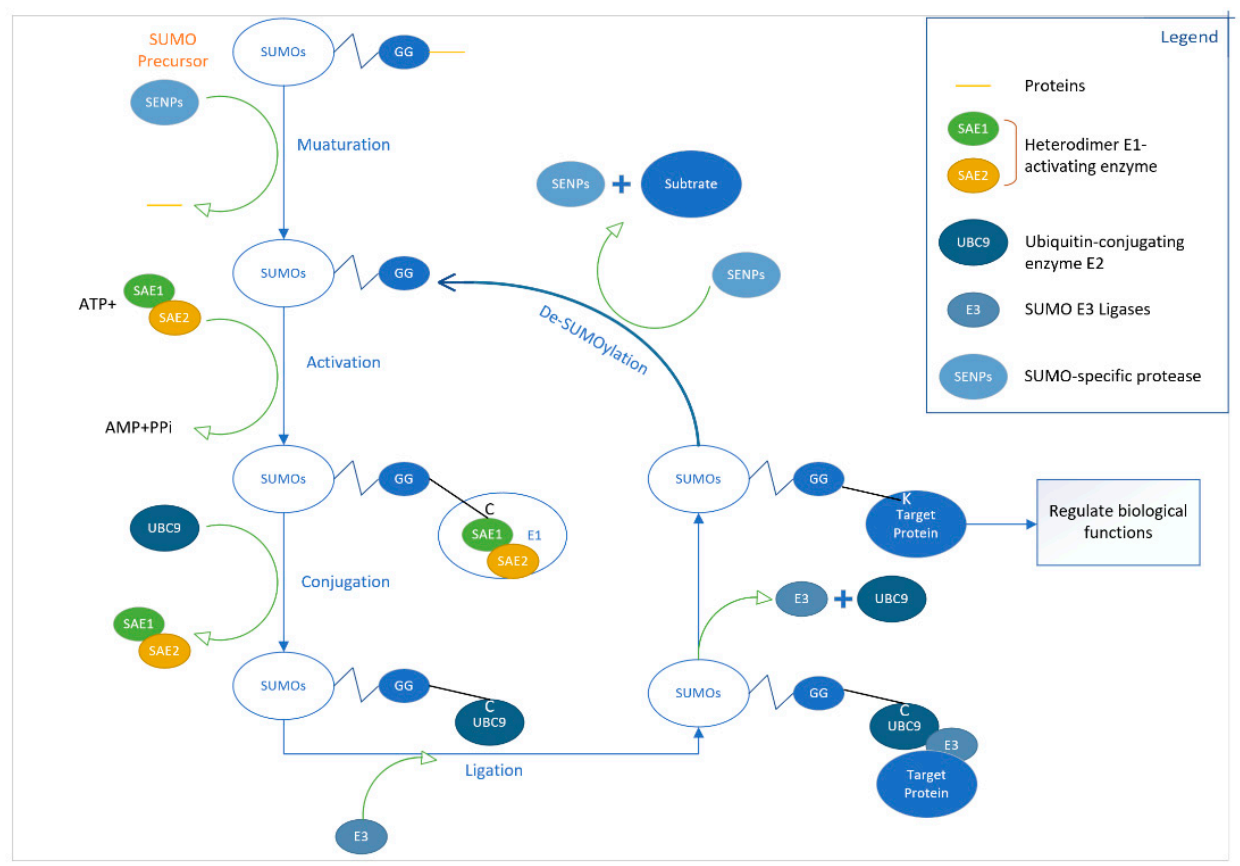

Figure 2. Schematic diagram showing the pathway related to protein SUMOylation. Maturation/deSUMOylation: SENPs cleave the SUMOs protein from the precursor protein to produce mature SUMO protein; Activation: A thioester bond is formed between the GG of the SUMO protein and the cysteine residue of SAE1/2; Conjugation: A thioester bond is formed between the GG of SUMO protein and the cysteine residue of Ubc9; Ligation: Ubc9 and E3 ligases catalyse GG and target substrate lysine residues to form isopeptide bonds.

There are five major protein subtypes in the SUMO family in mammals: SUMO1, SUMO2, SUMO3, SUMO4 and SUMO5. Family members are slightly different in length. SUMO1, SUMO2 and SUMO3 are expressed ubiquitously among species. SUMO1 is a 
polypeptide composed of 101 amino acids, which mainly modifies proteins in physiological states; SUMO2 and SUMO3 are composed of 101 and 95 amino acids, respectively. SUMO2 and SUMO3 have $97 \%$ sequence homology to each other, however, they are only about $50 \%$ homologous compared with SUMO1 [32]. They mainly modify proteins related to stress response [33]. The amino-terminus of SUMO2 and SUMO3 has a SUMO-binding conserved sequence, which can form SUMO multimers. SUMO multimers play a vital role in the intracellular localisation of target proteins and cooperative ubiquitination degradation. SUMO4, which is composed of 95 amino acid peptides, is only expressed in humans and pigs. It is mainly expressed in human kidneys and immune tissues (such as lymphatic tissues and spleen) [34]. SUMO5 is a recently discovered small ubiquitin-related modified protein. It is highly homologous to SUMO1 while characterised by two specificities: species specificity and tissue specificity. It is uniquely expressed in primates and actively transcribed in certain types of tissue, especially in testis and blood [35].

Similar to ubiquitination, SUMOylation is also a cyclical process, including growth, activation, binding and de-modification [36]. The SUMO gene is first expressed as an immature precursor protein [37]. This precursor protein has a short peptide with a length of approximately 2-11 amino acids at the C-terminus. Then the SUMO-specific enzyme Ubl-specific proteases (Ulps) cuts off the short peptide at the C-terminal end, exposing the Gly residue [38] and converting it into a mature functional SUMO protein. In mature SUMO protein-mediated SUMOylation, an isopeptide bond is formed between the C-terminal Gly residue and the Lys $\varepsilon$-amino group of the target protein.

The molecular cascades of protein SUMOylation involve multiple enzymes that similarly function in protein ubiquitination: E1 activating enzyme, E2 binding enzyme and E3 ligase, but the enzymes involved in the two reaction pathways are entirely different [38]. Bosis and Melchior [39] showed that a low concentration of reactive oxygen species (ROS) might recruit the SUMO E1 subunit Uba2 and E2 enzyme Ubc9 to catalyse the formation of disulphide bonds by cysteine, thereby preventing the formation of Ubc9-SUMO thioesters and inhibiting SUMO engages. SUMOylation is a dynamic and reversible modification process. The SUMO modification system can be regulated by regulating the expression of each component of the SUMO modification pathway and the activity of the SUMO enzymes. Extracellular stimuli can signal to the nucleus, triggering the rapid recruitment of the SUMO E3 ligase promoter, leading to immediate transcription repression. In addition, there is a specific protease in the cells that can remove SUMO from the modified protein, including de-SUMO enzymes in mammals, called SENP. They have different positioning, slightly different functions and different substrate specificities. SENP1 and SENP2 can separate SUMO1 and SUMO2/3 proteins. SUMO2/3 proteins mainly separate SENP3 and SENP5. SENP6 and SENP7 mainly decompose the multi-chain of SUMO2/3 [40]. It has been reported that SENPs are critical regulators of the SUMOylation regulatory mechanism. A study by Cui and Wong [41] showed that SENP1 significantly increased the stability and transcriptional activity of hypoxia-inducible factor $1 \alpha$ (HIF-1 $\alpha$ ) under hypoxic conditions through deSUMOylation [42].

Other post-translational modification events, such as phosphorylation, ubiquitination and acetylation, can regulate SUMOylation through cross-talk [43]. Phosphorylation can regulate the binding of SUMO to the target protein through the motif PDSM (phosphorylation-dependent SUMO motif) [44]. This phosphorylation-dependent SUMOylation regulation is called phosphorylation-SUMOylation switch. Similarly, in proteins such as the transcription factor Elk-1, an extended SUMO modification motif has been found, containing a cluster of acidic residues downstream of the SUMO core modification site [45]. The dependence of SUMO and substrate Conjugation of amino acid residues. Studies have shown that SUMO coupling can occur with the ubiquitin in specific proteins on the same lysine residue. For example, the competition between SUMOylation and ubiquitination on the same lysine residue regulates the stability of IкB $\alpha$ [46].

It should be noted that SUMOylation and ubiquitination are not entirely competitive. In some cases, SUMOylation can provide a signal to ubiquitin ligase [47]. For example, 
in the process of post-translational modification of the MEF2 protein, the SUMOylationacetylation switch is regulated by phosphorylation. These studies show the importance of signalling cross-talk in regulating protein SUMOylation [47].

\section{The Expression and Clinical Significance of SUMOs Proteins in HCC}

At present, there have been studies expounding the possible clinical applications of SUMOs protein. In the study of Jiann et al. [48], it was found that the mRNA levels of SAE1 in liver cancer tumour tissues were significantly upregulated $(p<0.0001)$. Patients with higher SAE1 mRNA have a worse disease survival rate (DSS) and progression-free survival rate (PFS). This is consistent with the role of SUMOylation proteins such as SUMO1 and Ubc9 in HCC. Research further shows that SAE1 is closely related to hypoxia and impaired metabolism [49]. Highly expressed SAE1 upregulates reactive oxygen species (ROS), glycolysis and cholesterol homeostasis pathway, indicating the potential of SAE1 as a biomarker for the prognosis of HCC [50]. In addition, Jennifer et al. discovered and produced a catalytically inactive recombinant fragment of the U.D. domain of KmUlp1, named KmUTAG [51]. KmUTAG can effectively and extensively bind to proteins in the SUMO family. The combined compound is highly stable and will not denature the protein even under extreme conditions. Through these experiments, they revealed the essential details of binding to the target protein in SUMOylation. More importantly, they predict that the recombinant fluorescent KmUTAG can visualise the distribution and flow of SUMO and SUMOylated proteins in living cells. It provides new ideas and methods for future research on the role of SUMOylation in HCC.

We extracted the mRNA expression levels of SUMO1, 2 and 3 in HCC tumour tissue and normal liver tissue, respectively from the GEPIA database. As shown in Figure 3 [52]: The expression of different SUMOs in HCC was retrieved from the GEPIA (http:/ / gepia. cancer-pku.cn/, accessed on 3 November 2021) database. The expression levels of SUMO1, SUMO2 and SUMO3 in liver cancer cells were significantly higher than those in normal cells $(p<0.01)$. This indicates that the SUMOs protein plays an essential role in the development of HCC and suggests the potential of SUMOs as future targets. These data and Jiann's research results are mutually corroborating, implying the potential of SUMOs as prognostic markers of HCC [48].

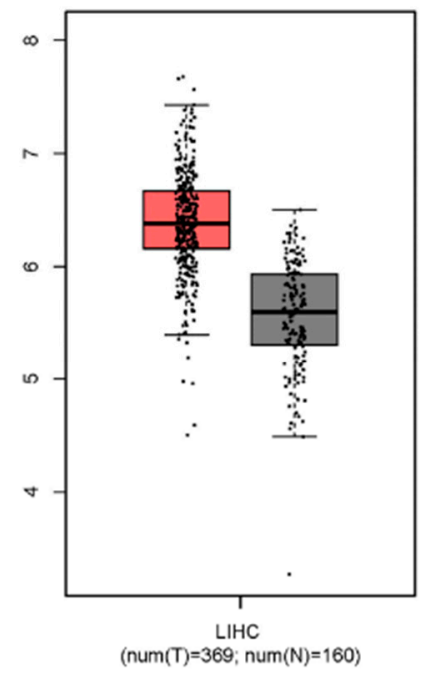

SUMO1

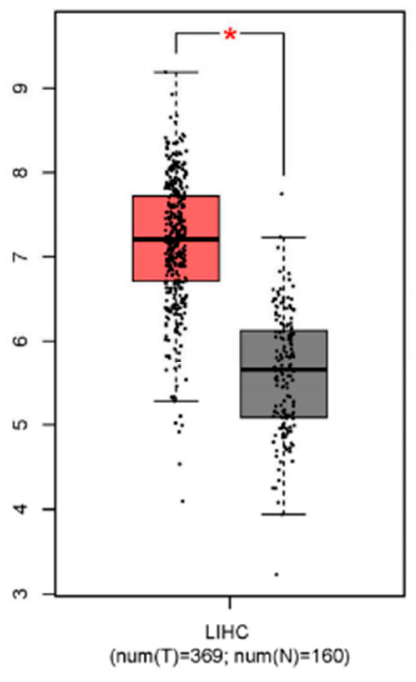

SUMO2

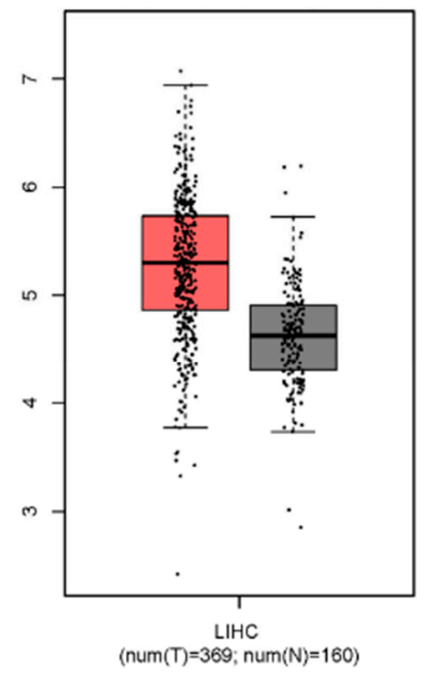

SUMO3

Figure 3. The expression differences of SUMOs mRNA in human HCC specimens. $\left({ }^{*} p<0.01\right.$, The ordinate is the expression amount represented by $\log 2(\mathrm{TPM}+1))$.

As shown in Figure 4 [52], we have also illustrated the relationship between the expression of SUMOs mRNA and the prognosis of HCC patients from GEPIA. The GEPIA 
(http:/ /gepia.cancer-pku.cn/, accessed on 3 November 2021) database shows that the expression level of SUMOs has a significant impact on the overall survival(OS) time of patients. As the figures are shown below, whether it is overall survival or disease-free survival (DFS). Patients with low expression levels of SUMOs have better prognosis and survival rates. These results suggest that SUMOs are abnormally expressed in human tumour tissues and SUMOs may be used as a new malignant tumour marker.
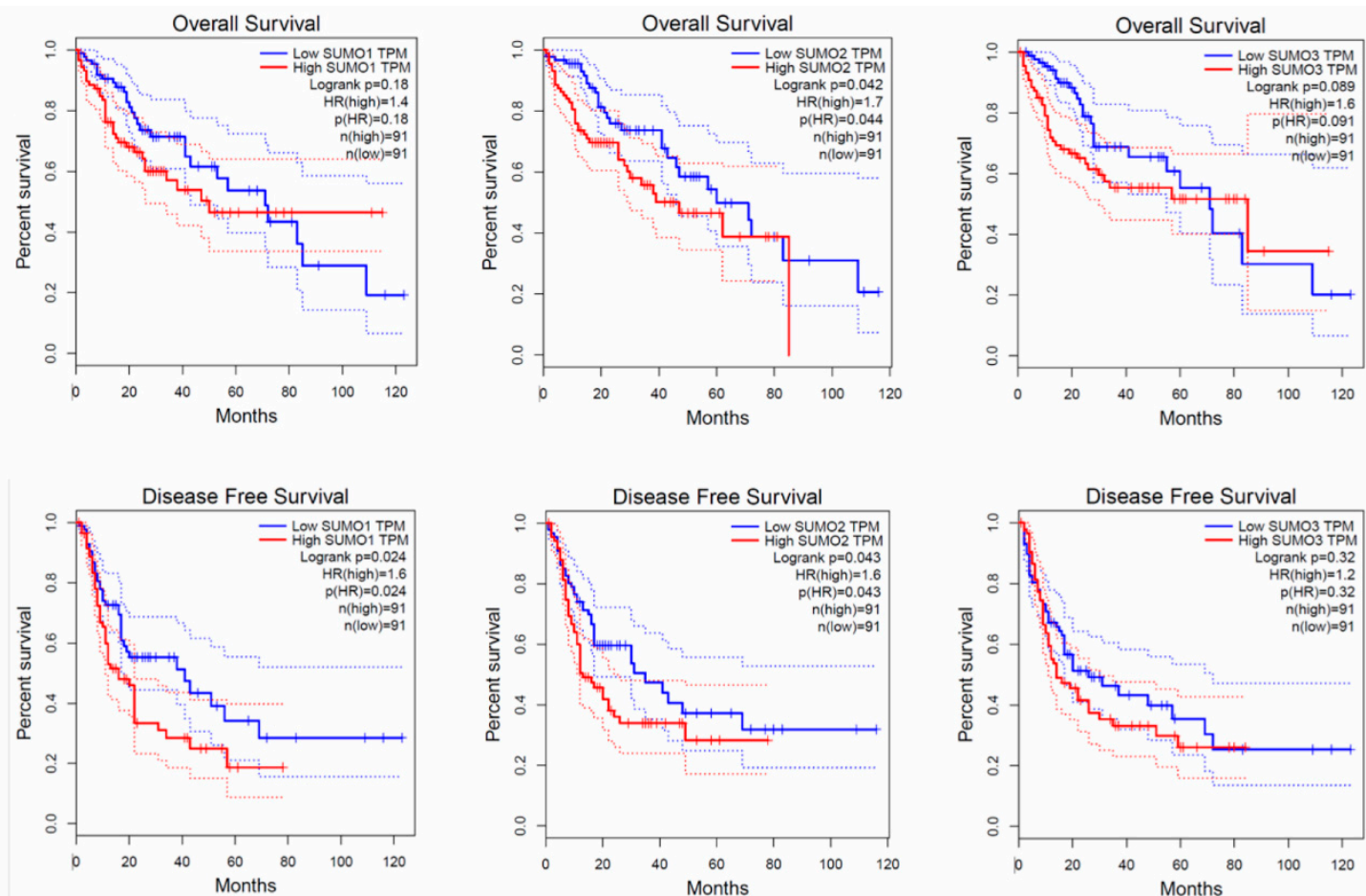

Figure 4. The prognosis value between the expression of SUMOs mRNA. The red line in the figure below represents patients with high expression of SUMOs mRNA and the blue line represents patients with low expression. Use $75 \%$ as the high cut-off and $25 \%$ as the low cut-off. Patients with low expression of SUMO protein had better OS and DFS than patients with high expression.

\section{The Role of Protein SUMOylation in HCC Progression \\ 4.1. SUMOylation in HCC Carcinogenesis}

Protein SUMOylation has been shown to maintain the steady-state balance of protein functions in normal tissues and various tumours. Increasing evidence indicated that the SUMO enzyme participates in carcinogenesis through a series of complex HCC mainly originates in the inflammatory environment of the (See Table 1 below).

Table 1. The Role of SUMOs in HCC progression.

\begin{tabular}{ccccc}
\hline \multirow{2}{*}{ Actions } & Models & $\begin{array}{c}\text { Regulation/ } \\
\text { Pathway }\end{array}$ & Effects & Reference \\
\hline & $\begin{array}{c}\text { In Vitro, MHCC97H, MHCC97L, } \\
\text { MHCC-LM and QGY7703Hep3B, } \\
\text { HepG2, Huh7, SMMC-7721, } \\
\text { BEL-7402, BEL-7404. } \\
\text { In vivo, male BALB/c nude mice } \\
\text { (5 weeks old) }\end{array}$ & SIRT1-FTO & $\begin{array}{c}\text { SUMO ligase E3 RANBP2 } \\
\text { promotes SIRT1-related FTP } \\
\text { down-regulation }\end{array}$ & [53] \\
\cline { 2 - 5 } & in vitro, HepG2 & IQGAP2 & $\begin{array}{c}\text { SUMOylation inhibits AKT } \\
\text { phosphorylation through } \\
\text { cross-talk, thereby inhibiting the } \\
\text { expression of HBV genes. }\end{array}$ & {$[54]$} \\
\hline
\end{tabular}


Table 1. Cont.

\begin{tabular}{|c|c|c|c|c|}
\hline Actions & Models & $\begin{array}{l}\text { Regulation/ } \\
\text { Pathway }\end{array}$ & Effects & Reference \\
\hline & $\begin{array}{l}\text { In vitro. HEK293T, SMMC-7721 } \\
\text { and HepG2 cells }\end{array}$ & ROS\&PHGDH & $\begin{array}{l}\text { SUMOylised NRF2 can } \\
\text { upregulate the synthesis of } \\
\text { serine in HCC. }\end{array}$ & $\begin{array}{l}{[50]} \\
2019\end{array}$ \\
\hline & $\begin{array}{l}\text { In vitro, SMMC-7721, HepG2 } \\
\text { and SMMC-7721-shShp2 }\end{array}$ & ERK & $\begin{array}{l}\text { Shp2 SUMOylation upregulates } \\
\text { the activation of ERK }\end{array}$ & $\begin{array}{l}{[55]} \\
2015\end{array}$ \\
\hline & $\begin{array}{c}\text { In vitro, HepG2, HepG2X, } \\
\text { Hep3B, SK-Hep1, HuH7 and } \\
\text { Hep3BX cells }\end{array}$ & CPAP & $\begin{array}{l}\text { TNF- } \alpha \text { can upregulate SUMO-1 } \\
\text { mediated CPAP SUMOylation, } \\
\text { which is very important for } \\
\text { NF- } \kappa \text { B co-activator activity. }\end{array}$ & $\begin{array}{l}{[56]} \\
2013\end{array}$ \\
\hline & $\begin{array}{c}\text { In Vitro, MHCC97H, HepG2, } \\
\text { HEP3B and SMMC-7721. } \\
\text { In vivo, Four-week-old female } \\
\text { BALB/c nude mice }\end{array}$ & $\begin{array}{l}\text { UBC9, } \\
\text { SUMOylated } \\
\text { Mettl3 and } \\
\text { Snail }\end{array}$ & $\begin{array}{l}\text { SUMOylate Mettls can regulate } \\
\text { the homeostasis of Snail mRNA } \\
\text { through m6A methyltransferase } \\
\text { activity-dependent manner. And } \\
\text { then regulate the development } \\
\text { of HCC. }\end{array}$ & $\begin{array}{l}{[57]} \\
2020\end{array}$ \\
\hline \multirow{9}{*}{$\begin{array}{l}\text { HCC proliferation and } \\
\text { survival }\end{array}$} & $\begin{array}{l}\text { in vitro, hepg2 and smmc7721 } \\
\text { In clinical, HCC patient }\end{array}$ & NF- $k B$ & $\begin{array}{c}\text { SUMO2/3 and P65 are } \\
\text { co-expressed and co-localised in } \\
\text { HCC. }\end{array}$ & $\begin{array}{l}{[58]} \\
2015\end{array}$ \\
\hline & $\begin{array}{l}\text { In vitro, MHCC97L } \\
\& S M M C-7721 \text { cells }\end{array}$ & $\mathrm{Cbx} 4$ & $\begin{array}{l}\text { CBx4 can control HIF- } 1 \alpha, \\
\text { thereby upregulating the } \\
\text { angiogenesis of HCC. SUMO's } \\
\text { E3 ligase controls this activity. }\end{array}$ & $\begin{array}{l}{[49]} \\
2014\end{array}$ \\
\hline & In vitro, HepG2 cells & WWOX & $\begin{array}{l}\text { WWOX can help SENP2 } \\
\text { stabilisation of } \beta \text {-catenin. }\end{array}$ & $\begin{array}{l}{[59]} \\
2014\end{array}$ \\
\hline & In-clinic, Patients HCC cells & HIF- $1 / 2 \alpha$ & $\begin{array}{l}\text { SENP1 can de-SUMOylation } \\
\text { HIF-1 } \alpha \text { and increase its stability. }\end{array}$ & $\begin{array}{l}{[60]} \\
2016\end{array}$ \\
\hline & In vitro, HepG2 cells & $N F-k B$ & $\begin{array}{c}\text { SUMO1 and P65 are } \\
\text { co-expressed and co-localised. } \\
\text { Up-regulation of SUMO1 can } \\
\text { upregulate NF- } \mathrm{kB} \text { activity and } \\
\text { promote the progression of HCC. }\end{array}$ & $\begin{array}{l}{[61]} \\
2016\end{array}$ \\
\hline & In vivo, Male BALB/c nude mice & ATR & $\begin{array}{l}\text { SUMOylation of ART can } \\
\text { upregulate the proliferation of } \\
\text { HCC cells. }\end{array}$ & $\begin{array}{l}{[62]} \\
2016\end{array}$ \\
\hline & $\begin{array}{l}\text { In vitro, human LCSC } \\
\text { In-clinic, } 60 \mathrm{HCC} \text { patients. }\end{array}$ & TRF2 & $\begin{array}{c}\text { HULC can enhance } \\
\text { phosphorylation, thereby } \\
\text { suppressing SUMOylation. }\end{array}$ & $\begin{array}{l}{[63]} \\
2016\end{array}$ \\
\hline & $\begin{array}{c}\text { in vitro, HEK293T, L02 normal } \\
\text { human hepatic cells, HepG2 } \\
\text { human hepatocellular }\end{array}$ & Lats & $\begin{array}{l}\text { The SUMOylation of Lats1 can } \\
\text { upregulate Hippo signalling. }\end{array}$ & $\begin{array}{l}{[64]} \\
2017\end{array}$ \\
\hline & $\begin{array}{l}\text { in vitro, Huh-7, Hep G2 and } \\
\text { PLC/PRF/5 and MLP-29 }\end{array}$ & lkb1 & $\begin{array}{l}\text { SUMO2-mediated SUMOylation } \\
\text { of LKB1 can affect its location in } \\
\text { cells and promote } \\
\text { carcinogenesis. }\end{array}$ & $\begin{array}{l}{[65]} \\
2020\end{array}$ \\
\hline \multirow{2}{*}{$\begin{array}{c}\text { HCC migration, } \\
\text { invasion and metastasis }\end{array}$} & $\begin{array}{c}\text { In vitro, PHHs, MHCC-97H and } \\
\text { HCCLM3. } \\
\text { In-clinic, human HCC patient }\end{array}$ & $\begin{array}{l}\text { P53 hnRNP } \\
\text { SUMOlyation }\end{array}$ & $\begin{array}{l}\text { The SUMOylation of hnRNP k } \\
\text { can activate the P53 signal, } \\
\text { thereby inhibiting tumour } \\
\text { progression. }\end{array}$ & $\begin{array}{l}{[66]} \\
2020\end{array}$ \\
\hline & $\begin{array}{c}\text { In vitro, Huh-7 and } \\
\text { HepG-2In-clinic, Cancer tissues } \\
\text { and Paracancerous tissues for } 38 \\
\text { patients. }\end{array}$ & $N F-k B$ & $\begin{array}{c}\text { The SUMOylation of NEMO can } \\
\text { upregulate the activity of NF- } k \mathrm{~B} \text {, } \\
\text { thereby promoting the invasion } \\
\text { of HCC. }\end{array}$ & $\begin{array}{l}{[24]} \\
2020\end{array}$ \\
\hline
\end{tabular}


Table 1. Cont.

\begin{tabular}{|c|c|c|c|c|}
\hline Actions & Models & $\begin{array}{l}\text { Regulation/ } \\
\text { Pathway }\end{array}$ & Effects & Reference \\
\hline & $\begin{array}{l}\text { In Vivo, MANF-KO [knockout] } \\
\text { mice } \\
\text { In-Clinic, Human HCC cells }\end{array}$ & NF-kB & $\begin{array}{l}\text { SUMO1 co-localises with P65 } \\
\text { and MANF. Thereby promoting } \\
\text { the interaction between P65 and } \\
\text { MANF. }\end{array}$ & $\begin{array}{l}{[25]} \\
2020\end{array}$ \\
\hline & $\begin{array}{c}\text { in vitro, Huh7, SK-Hep1, Hep3B, } \\
\text { Hep3BX, HepG2 and HepG2X } \\
\text { cells }\end{array}$ & HBx & $\begin{array}{l}\text { CPAP can upregulate the } \\
\text { SUMOylation of HBx. }\end{array}$ & $\begin{array}{l}{[67]} \\
2019\end{array}$ \\
\hline & in vivo, Hnf1a-null mice & mrR192/194 & SUMO2 is miR194's target. & $\begin{array}{l}{[68]} \\
2017\end{array}$ \\
\hline & In-clinic, HCC patient & hsp27 & $\begin{array}{l}\text { SUMO2/3 upregulated the } \\
\text { HSP27 protein level. }\end{array}$ & $\begin{array}{l}{[69]} \\
2017\end{array}$ \\
\hline & In vivo, $\mathrm{HBx}$ mice & IGF-II & $\begin{array}{l}\text { SUMOylation of E-cadherin } \\
\text { causes it to degrade. }\end{array}$ & $\begin{array}{l}{[70]} \\
2015\end{array}$ \\
\hline & In vitro, MHCC97L cells & $\mathrm{Cbx} 4$ & $\begin{array}{l}\text { Cbx4 can upregulate the } \\
\text { SUMOylation of HIF- } 1 \alpha \text { and } \\
\text { shape the hypoxic } \\
\text { microenvironment. }\end{array}$ & $\begin{array}{l}{[49]} \\
2014\end{array}$ \\
\hline & $\begin{array}{l}\text { In vitro, HepG2, Hep3B and } \\
\text { MHCC97H and standard liver } \\
\text { cancer cell lines THLE-2 and } \\
\text { LO2 }\end{array}$ & $\begin{array}{l}\text { Exportin-5 } \\
\text { (XPO5) }\end{array}$ & $\begin{array}{l}\text { SUMOylated XPO5 } \\
\text { down-regulating the } \\
\text { nucleo-cytoplasm transportation } \\
\text { of pre-miR-3184 }\end{array}$ & $\begin{array}{l}{[71]} \\
2020\end{array}$ \\
\hline \multirow{6}{*}{$\begin{array}{l}\text { HCC tumour } \\
\text { microenvironment }\end{array}$} & In Vitro, HCC cell line Hep3B & $\begin{array}{l}\text { HIF- } 1 \alpha \text { and } \\
\text { Oct } 4\end{array}$ & $\begin{array}{l}\text { deSUMOylation of HIF- } 1 \alpha \text { and } \\
\text { Oct4 reduced their accumulation } \\
\text { in the nucleus, thereby inhibiting } \\
\text { tumour angiogenesis and } \\
\text { stemness maintenance. }\end{array}$ & $\begin{array}{l}{[72]} \\
2020\end{array}$ \\
\hline & In-clinic, human blood samples & PKM2 & $\begin{array}{l}\text { SUMOylation of PKM2 induced } \\
\text { its plasma membrane targeting } \\
\text { and subsequent exosomal } \\
\text { excretion via interactions with } \\
\text { ARRDC1. }\end{array}$ & $\begin{array}{l}{[73]} \\
2020\end{array}$ \\
\hline & $\begin{array}{l}\text { in vitro, Hep3B cells } \\
\text { In-clinic, } 10 \text { HCC patients }\end{array}$ & SHh & $\begin{array}{l}\text { SUMOylation of GLI protein can } \\
\text { upregulate its } \\
\text { hypoxia-dependent activation. }\end{array}$ & $\begin{array}{l}{[74]} \\
2019\end{array}$ \\
\hline & In-clinic, HCC patients. & $N F-k B$ & $\begin{array}{l}\text { Sorafenib treatment treats HCC } \\
\text { by inhibiting the SUMOylation } \\
\text { of p } 65 .\end{array}$ & $\begin{array}{l}{[75]} \\
2018\end{array}$ \\
\hline & In vitro, HepG2 and SMMC-7721 & UBC9 & $\begin{array}{l}\text { UBC9 E2 conjugating enzyme is } \\
\text { necessary for the SUMOylation } \\
\text { process. }\end{array}$ & $\begin{array}{l}{[69]} \\
2017\end{array}$ \\
\hline & $\begin{array}{c}\text { In vitro, HepG2 } \\
\text { in-clinic, HCC patient }\end{array}$ & $\begin{array}{c}\text { not } \\
\text { mentioned }\end{array}$ & not mentioned & $\begin{array}{l}{[76]} \\
2015\end{array}$ \\
\hline
\end{tabular}

HCC mainly originates in the inflammatory environment of the liver. Extensive studies have shown that SUMO protein is an essential pathway for activating NF- $\mathrm{KB}$ [50,53-56]. SUMO protein can co-localise with P65 and affect the interaction of P65 with other proteins $[56,58]$. In short, SUMO protein can promote the canceration of liver cells in an inflammatory environment. Yen et al. found that TNF- $\alpha$-mediated SUMO-1 modification of CPAP is significant in the activation of NF-kB [67]. HBx can upregulate CPAP at the transcriptional level by interacting with CREB [56]. CPAP can interact with HBx to provide a microenvironment for the development of cancer cells. Inhibition of CPAP can inhibit 
the proliferation and migration of HCC. SUMOylated HBx enhances the interaction with $\mathrm{CPAP}$ and thereby promoting the carcinogenic effect of $\mathrm{HBx}$.

In addition to early carcinogenic events, it is evidenced that SUMO protein is essential in maintaining the carcinogenicity of HCC. Nuclear factor erythroid-2 related factor 2 (NRF2) is a transcription factor that can promote the progression of various cancer [77]. The NRF2 pathway can maintain redox homeostasis in the cell, making it indispensable in normal cells [78]. Compared with normal cells, cancer cells have unique metabolic characteristics. For example, to accelerate the synthesis of biological substances to achieve rapid value-added or improve tolerance to oxidative stress. The research of Guo and $\mathrm{Xu}$ showed that NRF2 is a crucial transcription factor that maintains cell redox homeostasis and promotes the phenotype of malignant tumours [78]. Reports have shown that NRF2 plays a key role in the metabolism of cancer cells. Abnormal activation of the NRF2 pathway in cancer cells leads to reprogramming of intermediate metabolism, supporting cancer cell proliferation and tumorigenesis. The SUMO protein regulates the functionality of NRF2. Inhibiting the SUMOylation of NRF2 can slow down the carcinogenesis of hepatocellular carcinoma. SUMO protein-mediated NRF2 SUMOylation can enhance the clearance rate of intracellular nutrient activity and promote the synthesis of serine-free HCC. In addition, HCC lacking serine increases the SUMOylation of NRF2 and promotes the process of HCC [50]. In short, SUMOylation of NRF2 can maintain the carcinogenicity of HCC in liver cancer cells and promote the growth and proliferation of HCC cells. At the same time, it can improve the tolerance of HCC cells to oxidative stress.

\subsection{SUMOylation in the Proliferation and Survival of HCC Cells}

The SUMOs signalling cascade is critical to gene expression, genome integrity and cell cycle progression [79]. The recent development of small molecule inhibitors has made possible the therapeutic targeting of the SUMO pathway. Blocking SUMOylation not only reduces the proliferation of cancer cells but also enhances the anti-tumour immune response by stimulating interferon signals, which indicates that the SUMOylation inhibitor has a dual mode of action (Table 1).

p65 is one of the most critical subunits of NF- $\mathrm{kB}$ and a key regulator in the development of HCC [80]. Studies have shown that p65 can be modified by exogenous SUMO3 and expressed in Human Embryonic Kidney Cells 293 (HEK-293) cells [58]. Liu and colleagues found that in HCC adjacent tissues, $\mathrm{SUMO} 2 / 3$ is expressed in large amounts in the cytoplasm [61]. However, in contrast, the level of SUMO2/3 in tumour tissues was down-regulated. Consistent with this result, the expression of p65 is also upregulated in adjacent tissues. Consistent with SUMO2/3, it is mainly located in the cytoplasm. This means that SUMO2/3 is closely related to the expression of p65 in liver tissue and is co-localised. The experiment further confirmed this conclusion by interacting with p65 and SUMO2/3 through immunoprecipitation and double-labelled immunofluorescence $(r=0.800, p=0.006)$ [61]. In addition, Liu et al. found that SUMO2/3 had a dose-dependent up-regulation of cytoplasmic p65 protein levels but did not affect its mRNA levels. At the same time, TNF- $\alpha$ induced an increase in the binding of SUMO2/3 to p65, accompanied by a decrease in ubiquitin binding to $\mathrm{p} 65$. Further studies have shown that the overexpression of SUMO2/3 reduces the proliferation ability of liver cancer cells but does not affect the migration of liver cancer cells.

The STAT4 (PIAS4) protein regulates various biological activities, including posttranslational modifications of the protein, such as SUMOylation. PIAS4, as an E3-SUMO ligase, can inhibit the functions of many proteins such as AMPK $\alpha$ and NEMO [81]. In the study of Liu and Zhou et al., the role of PIAS4 in hepatocellular carcinoma was explored [24]. To analyse the expression of PIAS4 in 38 cases of HCC patients with cancer tissues and adjacent tissues and its relationship with the prognosis of patients. The results showed that patients with upregulated PIAS4 levels in liver cancer tissues had a poor prognosis $(p<0.05)$. Highly expressed PIAS4 promotes the SUMOylation of AMPK $\alpha$ and NEMO. 
This leads to the proliferation, migration and invasion of HCC cells. This indicates that PIAS4 promotes the progress of HCC by promoting SUMOylation of and NEMO [24].

Large tumour suppressor genes (Lats) can enhance the homeostasis of cells. Furthermore, it can mediate Hippo's inhibitory signal [82]. Liu and Mei et al. found that SUMO of Lats1 affects its kinase activity, especially Hippo signal transduction [64]. SUMO1 interacts directly with Lats1 and the loss of SUMO pathway function interferes with the SUMOylation of Lats1. The SUMOylation of Lats1 reduces the phosphorylation of Lats1 through antagonism, leading to the weakening of Lats1 kinase activity and inhibition of Hippo signalling. In addition, more SUMO-Lats1 conjugates can be detected in cancer cells. Eventually, promote the proliferation and survival of liver cancer cells.

\subsection{SUMOylation in the Migration, Invasion and Metastasis of HCC}

SUMO proteins are also necessary for the metastasis and invasion of HCC. It is mainly achieved through the signal pathway that affects NF-kB $[24,25,66,72]$. Interestingly, SUMO protein can promote and inhibit the metastasis of HCC. This reflects the diversity of SUMO protein substrates and the complexity of SUMO protein in the HCC process.

During endoplasmic reticulum stress, the secretion of astrocyte-derived neurotrophic factor (MANF) from the right to midbrain can be upregulated. MANF can interact with P65 to inhibit P65-mediated inflammation [25]. Liu and Wu's research found that: in HCC tissues, the mRNA and protein levels of MANF are significantly lower than those of adjacent tissues [25]. Follow-up of the prognostic level of patients found that the inflammatory microenvironment in the tumours of patients with low MANF levels is more extensive. Patients with higher levels of MANF have better disease-free survival and overall survival. At the same time, in vitro experiments show that MANF can also inhibit the metastasis and invasion of liver cancer cells. MANF promotes the hepatocyte-specific depletion of HCC induced by n-nitrosodiethylamine (DEN) by upregulating the level of Snail1 $/ 2$ and promoting the epithelial-mesenchymal transition (EMT) of HCC cells. MANF is located in the nucleus and co-localises with liver cancer cells treated with p65 and tumour necrosis factor- $\alpha$ (TNF- $\alpha$ ) in liver cancer tissues. SUMO1 mediated MANF SUMOylation can promote the nuclear translocation of MANF and enhance the interaction between MANF and p65, thereby inhibiting the growth and metastasis of HCC.

In Liu and Tao's experiments, the interaction of SUMO1 and P65 accelerated the process of HCC. P65 is upregulated in liver tumour tissues and is related to liver cancer [30]. SUMOylation and regulation of various intracellular processes, such as nuclear import of targeted proteins. The nuclear transport of p65 leads to the activation of NF- $\mathrm{kB}$ and p65 contains multiple SUMO interacting sequences (SIM). The potential role of SUMO1 in HCC is demonstrated by regulating the subcellular localisation of p65. The results showed that in the tumour tissues of HCC patients, the positive immune response of SUMP1 and P65 was significantly higher than that of adjacent tissues. The data showed that there was a positive correlation between the positive immune response of SUMO1 and P65 ( $\mathrm{r}=0.851, p=0.002)$ [30]. It is speculated that the up-regulation of TNF- $\alpha$ and the hypoxic environment both upregulate the SUMO1-modified P65 SUMOylation. SUMO1 can upregulate the nuclear translocation of $\mathrm{P} 65$ and promote the transcriptional activity of NF-KB.

The above two studies have shown that SUMO1 can co-localise with P65, thereby affecting cell function. Nevertheless, it is interacting with different objects and led to the opposite result. This shows that the SUMOs protein is not limited to a simple factor determining the fate of HCC. The mechanism and critical points need to be further studied.

\subsection{SUMOylation in the Tumour Microenvironment of HCC}

The tumour and the supportive tumour microenvironment (TME) interact and promote each other [83]. The structure of TME includes tumour-infiltrating monocytes/macrophages, immunosuppressive cells, fibroblasts, blood vessels and secreted inflammatory factors [84]. In TME, liver cancer cells can target and perceive stromal cells and hijack the surrounding 
normal cells to support their development [85]. Tumour-infiltrating macrophages are one of the most abundant stromal cell types in HCC TME. They inhibit anti-tumour immunity and secrete various inflammatory mediators by inducing extracellular matrix remodelling, angiogenesis, metastasis and treatment resistance. Promote tumour progression [85]. These macrophages are mainly derived from circulating monocyte precursor cells and differentiate into mature macrophages under regulatory factors derived from tumour cells. Tumour-derived extracellular vesicles are essential mediators of cell-to-cell communication during tumorigenesis and development [86]. Hou et al. proved that extracellular bodies derived from hepatocellular carcinoma rebuild the tumour microenvironment and promote the progression of liver cancer in a PKM2-dependent manner [73]. HCC-derived exosomes PKM2 induce the metabolic reprogramming of monocytes and the phosphorylation of STAT3 in the nucleus, thereby upregulating differentiation-related transcription factors, leading to monocyte-macrophage differentiation and tumour microenvironment remodelling. In liver cancer cells, SUMOylation of PKM2 induces plasma membrane targeting and exosomal excretion through interaction with ARRDC1. Cytokines/chemokines secreted by macrophages strengthen the connection of PKM2-ARRDC1 in liver cancer in a CCL1-CCR8 axis-dependent manner, further promoting the secretion of PKM2 in the liver cancer cells, and forming a feedforward regulatory loop. Clinically, extracellular PKM2 can be detected in the plasma of patients with hepatocellular carcinoma. This study highlights the mechanism by which extracellular PKM2 reshapes the tumour microenvironment and reveals the possibility of extracellular PKM2 as a diagnostic marker for hepatocellular carcinoma.

\subsection{SUMOylation in HCC Drug Resistance}

The low cure rate and poor prognosis of HCC are closely related to the easy development of drug resistance in HCC [3]. There are many reasons for the development of drug resistance in HCC. Such as the specific hypoxic microenvironment in solid tumours, mutations of tumour suppressor genes, or abnormal expression of cell membrane transporters [3]. These factors will lead to the evolution of tumour cell icons, structure and function. This leads to HCC insensitivity to drugs, drug resistance and chemotherapy failure [87]. As mentioned above, hypoxia is an essential feature of HCC. Under hypoxic conditions, the SUMOylation of GLI proteins can be upregulated [74]. GLI is an essential mediator of the SHh pathway signal transfer [88]. SHh can promote the drug resistance of liver cancer cells, so it has become an essential target for the development of drug resistance. Zhang et al. found that under hypoxic conditions, Ssd can inhibit the malignant characteristics of liver cancer cells. In addition, it can also enhance the sensitivity of HSV, GCV and other chemotherapeutic drugs [74]. At the same time, Ssd can promote SENP5-mediated GLI de-SUMOylation and down-regulate the expression and interaction of SUMO1 and GLI. Thereby slowing down the drug resistance of HCC and enhancing the effect of chemotherapy. The adjustment of Ssd depends on time and dose. The higher the dose, the longer the action time and the stronger the inhibitory effect on GLI and SUMO1.

UBC9 is the only consistent SUMO protein E2 enzyme [89]. It is an essential protein in the SUMO-mediated Summarisation process. It plays a vital role in the cell cycle, apoptosis regulation, DNA damage repair and gene transcription [90]. At the same time, it is also crucial in the nuclear and cytoplasmic transport of proteins [91]. Reports show that overexpression of UBC9 can promote drug resistance in breast cancer cells [92,93]. In the experiment of Fang and Qiu, the mechanism of UBC9-mediated SUMOylation on chemotherapy resistance of liver cancer cells was explored. Experiments have found that the expression of UBC9 in HCC is significantly upregulated compared with adjacent tissues [60]. The magnitude of up-regulation is positively correlated with tumour size and density. After down-regulating the expression of UBC9 through shRNG overexpression, the drug resistance of cancer cells was inhibited. It indicates that UBC9 may be related to the drug resistance of liver cancer cells. Silencing the SUMO E2 gene UBC9 may inhibit the generation of HCC resistance and is a potential target for the treatment of HCC. 


\subsection{SUMOs Related Drugs}

Growing evidence has shown that SUMO protein plays a crucial role in the entire process of HCC. Potentially, the regulation on the expression of SUMO protein may interfere with the process of $\mathrm{HCC}$, which makes SUMO a promising target for $\mathrm{HCC}$ treatment. At the same time, different expression levels of SUMO protein can regulate the sensitivity of HCC to chemotherapy and have a certain impact on HCC resistance [94]. The expression of SUMO protein is also related to the prognosis and can be used as an indicator to detect the prognostic effect. However, there is no current SUMOylation-related drug on the market. Only one SUMO-related drug is undergoing clinical trials. SAE (SAE1, SAE2, UBA2) is the activating enzyme of SUMO. In the enzyme cascade of SUMOylation, the ATP-dependent process catalysed by SAE can activate the SUMO protein [23]. TAK-981 is an SAE-based SUMOylation inhibitor [95]. A SUMO-TAK-981adduct can be formed as a site to inhibit SUMOylation (NCT number: NCT03648372, NCT04065555, NCT04074330, NCT04776018 and NCT04381650). The clinical trials of TAK-981 are still in progress, so follow-up data is needed for discussion. In addition, the effect of TAK-981 in HCC is currently poorly understood and further testing is needed.

\section{Discussion}

As mentioned above, there are currently no commercially available SUMO drugs, studies have shown that some natural compounds can regulate the SUMO process. For example, according to the study of Fukuda et al., ginkgolic acid and its analogues have an inhibitory effect on SUMOylation and do not affect ubiquitination in the body [96]. Ginkgo acid was directly bound to SAE1 and can inhibit the formation of E1-SUMO intermediates [97] and thus inhibited SUMOylation in the body. These studies will provide valuable tools for studying the role of SUMO conjugates in various pathways in cells and provide a basis for the development of drugs for diseases involved in abnormal Summarisation. Similarly, another natural compound named Kerriamycin B was reported to act as a SUMOylation cascade inhibitor by explicitly binding to E1 [98].

Spectinomycin B is a natural antibiotic. Unlike ginkgolic acid or kerriamycin B, spectinomycin $\mathrm{B} 1$ directly binds to $\mathrm{E} 2$ ( $\mathrm{Ubc} 9$ ) and selectively prevents the formation of the E2-SUMO intermediate. In other words, Ubc9 is the direct target of spectinomycin B1 [99].

Triptolide is another natural modulator of the SUMOylation cascade [100]. According to the research of Huang and colleagues, Triptolide can down-regulate the mRNA and protein expression levels of SENP1, thus inhibiting the occurrence of deSUMOylation and maintaining the level of SUMOylation. Its anti-tumour activity may be related to the downregulation of SENP1 to restore the balance of SUMOylation and de-SUMOyaltion. Momordin Ic (Mc) is another SUMOylation cascade modulator for SENP1. Mc reduces the cleavage of SUMO2- $\triangle$ RanGAP1 and also changes the thermal stability of SENP1. Consistent with this, Mc increased the level of SUMOylated protein [101]. Indeed, Mc has potential therapeutic value for prostate cancer, but its role in HCC needs further research.

Unfortunately, there are currently no detailed data on the specific effects of these natural compounds in HCC. Most of the experiments are done in vitro or with the virus. Only momordin-Ic has been shown to inhibit the growth of prostate cancer cells in vivo and in vitro [101]. But the performance of momordin-Ic in HCC is not yet researched. In addition, the inhibitory effects of these natural compounds on SUMOs have not yet been quantified. Only ginkgolic acid has been shown to have a strong inhibitory effect on SUMOylation. In $72 \mathrm{~h}$ of treatment, $10 \mu \mathrm{M}$ of ginkgolic acid can significantly inhibit the activity of SUMO-1 [102]. The natural compounds found so far that can interact with SUMOs proteins are all SUMOylation inhibitors. The use of these compounds can better study the significance of inhibiting SUMOylation in HCC. At the same time, according to current research, these SUMOs inhibitors also can become an adjuvant therapy for HCC. 


\section{Conclusions}

SUMO modification is an essential post-translational modification, which has been shown to play a crucial role in various processes of HCC. This article reviews the role of SUMOylation in HCC carcinogenesis, proliferation and survival, metastasis and invasion, tumour microenvironment and HCC drug. In general, SUMO1 and SUMO2/3 have a promoting effect in all stages of HCC development. SUMOylation rarely directly promotes the development of cancer. It is an indirect way to enhance the carcinogenic effect of its target proteins. For example, co-localisation with carcinogenic factors (LKB1), strengthening the stability of carcinogenic factors ( $\beta$-catenin), or a necessary condition for carcinogenic factor activity (Cbx4). It is worth noticing that SUMOs do not always promote the development of HCC. For example, SUMO1-mediated MANF SUMOylation can enhance the interaction between MANF and p65, thereby inhibiting the growth and metastasis of HCC. Overall, recent studies have shown the potential of SUMO1 and SUMO2/3 as therapeutic targets and prognostic markers for HCC. A drug-related to SUMO, TAK-981, is undergoing clinical trials. Nevertheless, there is currently no data for TAK-981 and HCC. Moreover, studies have shown that some natural compounds can regulate the expression of SUMO, but this regulation has not been confirmed in the liver. Translating these potentials into treatments and verifying the effects of these potentials in clinical treatment may be the focus and direction of future research.

Author Contributions: N.W. and Y.F. conceived and design the study, H.Y. retrieved data and draft the manuscript, Y.L., Y.-T.C. and C.Z. revised the manuscript. All authors have read and agreed to the published version of the manuscript.

Funding: This research was partially supported by the Research Council of the University of Hong Kong (project codes: 104004092 and 104004460), the Wong's donation (project code: 200006276), a donation from the Gaia Family Trust of New Zealand (project code: 200007008), the Research Grants Committee (RGC) of Hong Kong, HKSAR (Project Codes: 740608, 766211, 17152116, 17121419 and 17119621), the Health and Medical Research Fund (Project code: 15162961 and 16172751), Chinese Medicine Development Fund (Project Code: AR200001 and AR200032), the Enhanced new staff start-up fund (Project code: 204610519) and the Pre-emptive retention fund (Project code: 202007002).

Acknowledgments: The authors would like to express their appreciation to Keith Wong, Cindy Lee and Alex Shek for their technical supports.

Conflicts of Interest: Authors declare no conflict of interest in this study.

\section{References}

1. Sung, H.; Ferlay, J.; Siegel, R.L.; Laversanne, M.; Soerjomataram, I.; Jemal, A.; Bray, F. Global Cancer Statistics 2020: GLOBOCAN Estimates of Incidence and Mortality Worldwide for 36 Cancers in 185 Countries. CA Cancer J. Clin. 2021, 71, 209-249. [CrossRef]

2. Huang, J.; Lok, V.; Ngai, C.H.; Chu, C.; Patel, H.K.; Thoguluva Chandraseka, V.; Zhang, L.; Chen, P.; Wang, S.; Lao, X.Q.; et al. Disease Burden, Risk Factors, and Recent Trends of Liver Cancer: A Global Country-Level Analysis. Liver Cancer 2021, 10, 330-345. [CrossRef]

3. Chen, Z.H.; Zhang, X.P.; Lu, Y.G.; Li, L.Q.; Chen, M.S.; Wen, T.F.; Jia, W.D.; Zhou, D.; Li, J.; Yang, D.H.; et al. Actual long-term survival in HCC patients with portal vein tumor thrombus after liver resection: A nationwide study. Hepatol. Int. 2020, 14, 754-764. [CrossRef] [PubMed]

4. Cerrito, L.; Santopaolo, F.; Monti, F.; Pompili, M.; Gasbarrini, A.; Ponziani, F.R. Advances in pharmacotherapeutics for hepatocellular carcinoma. Expert Opin. Pharmacother. 2021, 22, 1343-1354. [CrossRef] [PubMed]

5. Dipasquale, A.; Marinello, A.; Santoro, A. A Comparison of Lenvatinib versus Sorafenib in the First-Line Treatment of Unresectable Hepatocellular Carcinoma: Selection Criteria to Guide Physician's Choice in a New Therapeutic Scenario. J. Hepatocell Carcinoma 2021, 8, 241-251. [CrossRef] [PubMed]

6. Huang, A.; Yang, X.R.; Chung, W.Y.; Dennison, A.R.; Zhou, J. Targeted therapy for hepatocellular carcinoma. Signal Transduct. Target Ther. 2020, 5, 146. [CrossRef] [PubMed]

7. Drazic, A.; Myklebust, L.M.; Ree, R.; Arnesen, T. The world of protein acetylation. Biochim. Biophys. Acta 2016, $1864,1372-1401$. [CrossRef]

8. Philippi, S.; Lorain, S.; Beley, C.; Peccate, C.; Précigout, G.; Spuler, S.; Garcia, L. Dysferlin rescue by spliceosome-mediated pre-mRNA trans-splicing targeting introns harbouring weakly defined 3' splice sites. Hum. Mol. Genet. 2015, 24, 4049-4060. [CrossRef] 
9. Singh, V.; Ram, M.; Kumar, R.; Prasad, R.; Roy, B.K.; Singh, K.K. Phosphorylation: Implications in Cancer. Protein J. $2017,36,1-6$. [CrossRef]

10. Vu, L.D.; Gevaert, K.; De Smet, I. Protein Language: Post-Translational Modifications Talking to Each Other. Trends Plant Sci. 2018, 23, 1068-1080. [CrossRef]

11. Matsumura, T.; Nakamura-Ishizu, A.; Muddineni, S.; Tan, D.Q.; Wang, C.Q.; Tokunaga, K.; Tirado-Magallanes, R.; Sian, S.; Benoukraf, T.; Okuda, T.; et al. Hematopoietic stem cells acquire survival advantage by loss of RUNX1 methylation identified in familial leukemia. Blood 2020, 136, 1919-1932. [CrossRef]

12. Bidoia, C. Human T-lymphotropic virus proteins and post-translational modification pathways. World J. Virol. 2012, 1, 115-130. [CrossRef] [PubMed]

13. Hamam, H.J.; Palaniyar, N. Post-Translational Modifications in NETosis and NETs-Mediated Diseases. Biomolecules 2019, 9 , 369. [CrossRef]

14. Li, Z.; Li, M.; Wang, D.; Hou, P.; Chen, X.; Chu, S.; Chai, D.; Zheng, J.; Bai, J. Post-translational modifications of EZH2 in cancer. Cell Biosci. 2020, 10, 143. [CrossRef] [PubMed]

15. Lachiondo-Ortega, S.; Mercado-Gómez, M.; Serrano-Maciá, M.; Lopitz-Otsoa, F.; Salas-Villalobos, T.B.; Varela-Rey, M.; Delgado, T.C.; Martínez-Chantar, M.L. Ubiquitin-Like Post-Translational Modifications (Ubl-PTMs): Small Peptides with Huge Impact in Liver Fibrosis. Cells 2019, 8, 1575. [CrossRef]

16. Li, Z.; Hou, P.; Fan, D.; Dong, M.; Ma, M.; Li, H.; Yao, R.; Li, Y.; Wang, G.; Geng, P.; et al. The degradation of EZH2 mediated by lncRNA ANCR attenuated the invasion and metastasis of breast cancer. Cell Death Differ. 2017, 24, 59-71. [CrossRef] [PubMed]

17. Dou, L.; Yang, F.; Xu, L.; Zou, Q. A comprehensive review of the imbalance classification of protein post-translational modifications. Brief Bioinform. 2021, 22, bbab089. [CrossRef]

18. Balmik, A.A.; Chinnathambi, S. Methylation as a key regulator of Tau aggregation and neuronal health in Alzheimer's disease. Cell Commun. Signal. 2021, 19, 51. [CrossRef]

19. Wu, Z.; Jankowski, V.; Jankowski, J. Irreversible post-translational modifications-Emerging cardiovascular risk factors. Mol. Aspects Med. 2021, 101010. [CrossRef]

20. García-Giménez, J.L.; Garcés, C.; Romá-Mateo, C.; Pallardó, F.V. Oxidative stress-mediated alterations in histone post-translational modifications. Free Radic. Biol. Med. 2021, 170, 6-18. [CrossRef]

21. Jansen, N.S.; Vertegaal, A.C.O. A Chain of Events: Regulating Target Proteins by SUMO Polymers. Trends Biochem. Sci. 2021, 46, 113-123. [CrossRef] [PubMed]

22. Zhao, X. SUMO-Mediated Regulation of Nuclear Functions and Signaling Processes. Mol. Cell 2018, 71, 409-418. [CrossRef] [PubMed]

23. Zhao, B.; Villhauer, E.B.; Bhuripanyo, K.; Kiyokawa, H.; Schindelin, H.; Yin, J. SUMO-mimicking peptides inhibiting protein SUMOylation. ChemBiochem 2014, 15, 2662-2666. [CrossRef] [PubMed]

24. Liu, Q.; Zhou, B.; Liao, R.; Zhou, X.; Yan, X. PIAS4, upregulated in hepatocellular carcinoma, promotes tumorigenicity and metastasis. J. Cell Biochem. 2020, 121, 3372-3381. [CrossRef]

25. Liu, J.; Wu, Z.; Han, D.; Wei, C.; Liang, Y.; Jiang, T.; Chen, L.; Sha, M.; Cao, Y.; Huang, F.; et al. Mesencephalic Astrocyte-Derived Neurotrophic Factor Inhibits Liver Cancer Through Small Ubiquitin-Related Modifier (SUMO)ylation-Related Suppression of NF-кB/Snail Signaling Pathway and Epithelial-Mesenchymal Transition. Hepatology 2020, 71, 1262-1278. [CrossRef]

26. Bian, X.L.; Chen, H.Z.; Yang, P.B.; Li, Y.P.; Zhang, F.N.; Zhang, J.Y.; Wang, W.J.; Zhao, W.X.; Zhang, S.; Chen, Q.T.; et al. Nur77 suppresses hepatocellular carcinoma via switching glucose metabolism toward gluconeogenesis through attenuating phosphoenolpyruvate carboxykinase sumoylation. Nat. Commun. 2017, 8, 14420. [CrossRef]

27. Shen, Z.; Pardington-Purtymun, P.E.; Comeaux, J.C.; Moyzis, R.K.; Chen, D.J. UBL1, a human ubiquitin-like protein associating with human RAD51/RAD52 proteins. Genomics 1996, 36, 271-279. [CrossRef]

28. Tammsalu, T.; Matic, I.; Jaffray, E.G.; Ibrahim, A.F.; Tatham, M.H.; Hay, R.T. Proteome-wide identification of SUMO modification sites by mass spectrometry. Nat. Protoc. 2015, 10, 1374-1388. [CrossRef]

29. Vidal, S.; Bouzaher, Y.H.; El Motiam, A.; Seoane, R.; Rivas, C. Overview of the regulation of the class IA PI3K/AKT pathway by SUMO. Semin. Cell Dev. Biol. 2021. [CrossRef]

30. Chen, L.; Liu, S.; Tao, Y. Regulating tumor suppressor genes: Post-translational modifications. Signal Transduct. Target Ther. 2020, 5, 90. [CrossRef]

31. Keiten-Schmitz, J.; Wagner, K.; Piller, T.; Kaulich, M.; Alberti, S.; Müller, S. The Nuclear SUMO-Targeted Ubiquitin Quality Control Network Regulates the Dynamics of Cytoplasmic Stress Granules. Mol. Cell 2020, 79, 54-67.e57. [CrossRef] [PubMed]

32. Tomanov, K.; Ziba, I.; Bachmair, A. SUMO Chain Formation by Plant Enzymes. Methods Mol. Biol. 2016, 1450, 97-105. [CrossRef]

33. Enserink, J.M. Sumo and the cellular stress response. Cell Div. 2015, 10, 4. [CrossRef]

34. Han, Z.J.; Feng, Y.H.; Gu, B.H.; Li, Y.M.; Chen, H. The post-translational modification, SUMOylation, and cancer (Review). Int. J. Oncol. 2018, 52, 1081-1094. [CrossRef] [PubMed]

35. Liang, Y.C.; Lee, C.C.; Yao, Y.L.; Lai, C.C.; Schmitz, M.L.; Yang, W.M. SUMO5, a Novel Poly-SUMO Isoform, Regulates PML Nuclear Bodies. Sci. Rep. 2016, 6, 26509. [CrossRef]

36. Hay, R.T. SUMO: A history of modification. Mol. Cell 2005, 18, 1-12. [CrossRef]

37. Drag, M.; Salvesen, G.S. DeSUMOylating enzymes-SENPs. IUBMB Life 2008, 60, 734-742. [CrossRef] 
38. Linova, M.Y.; Risør, M.W.; Jørgensen, S.E.; Mansour, Z.; Kaya, J.; Sigurdarson, J.J.; Enghild, J.J.; Karring, H. A novel approach for production of an active N-terminally truncated Ulp1 (SUMO protease 1) catalytic domain from Escherichia coli inclusion bodies. Protein Expr. Purif. 2020, 166, 105507. [CrossRef] [PubMed]

39. Bossis, G.; Melchior, F. Regulation of SUMOylation by reversible oxidation of SUMO conjugating enzymes. Mol. Cell 2006, 21, 349-357. [CrossRef]

40. Tokarz, P.; Woźniak, K. SENP Proteases as Potential Targets for Cancer Therapy. Cancers 2021, 13, 2059. [CrossRef]

41. Cui, C.P.; Wong, C.C.; Kai, A.K.; Ho, D.W.; Lau, E.Y.; Tsui, Y.M.; Chan, L.K.; Cheung, T.T.; Chok, K.S.; Chan, A.C.Y.; et al. SENP1 promotes hypoxia-induced cancer stemness by HIF-1 $\alpha$ deSUMOylation and SENP1/HIF-1 $\alpha$ positive feedback loop. Gut 2017, 66, 2149-2159. [CrossRef]

42. You, L.; Wu, W.; Wang, X.; Fang, L.; Adam, V.; Nepovimova, E.; Wu, Q.; Kuca, K. The role of hypoxia-inducible factor 1 in tumor immune evasion. Med. Res. Rev. 2021, 41, 1622-1643. [CrossRef] [PubMed]

43. Tomasi, M.L.; Ramani, K. SUMOylation and phosphorylation cross-talk in hepatocellular carcinoma. Transl. Gastroenterol. Hepatol. 2018, 3, 20. [CrossRef]

44. Hietakangas, V.; Anckar, J.; Blomster, H.A.; Fujimoto, M.; Palvimo, J.J.; Nakai, A.; Sistonen, L. PDSM, a motif for phosphorylationdependent SUMO modification. Proc. Natl. Acad. Sci. USA 2006, 103, 45-50. [CrossRef]

45. Im, H.J.; Sharrocks, A.D.; Lin, X.; Yan, D.; Kim, J.; van Wijnen, A.J.; Hipskind, R.A. Basic fibroblast growth factor induces matrix metalloproteinase-13 via ERK MAP kinase-altered phosphorylation and sumoylation of Elk-1 in human adult articular chondrocytes. Open Access Rheumatol. 2009, 1, 151-161. [CrossRef]

46. Arbel, M.; Bronstein, A.; Sau, S.; Liefshitz, B.; Kupiec, M. Access to PCNA by Srs2 and Elg1 Controls the Choice between Alternative Repair Pathways in Saccharomyces cerevisiae. mBio 2020, 11, e00705-20. [CrossRef]

47. Van Cuijk, L.; van Belle, G.J.; Turkyilmaz, Y.; Poulsen, S.L.; Janssens, R.C.; Theil, A.F.; Sabatella, M.; Lans, H.; Mailand, N.; Houtsmuller, A.B.; et al. SUMO and ubiquitin-dependent XPC exchange drives nucleotide excision repair. Nat. Commun. 2015, 6, 7499. [CrossRef] [PubMed]

48. Ong, J.R.; Bamodu, O.A.; Khang, N.V.; Lin, Y.K.; Yeh, C.T.; Lee, W.H.; Cherng, Y.G. SUMO-Activating Enzyme Subunit 1 (SAE1) Is a Promising Diagnostic Cancer Metabolism Biomarker of Hepatocellular Carcinoma. Cells 2021, 10, 178. [CrossRef]

49. Li, J.; Xu, Y.; Long, X.D.; Wang, W.; Jiao, H.K.; Mei, Z.; Yin, Q.Q.; Ma, L.N.; Zhou, A.W.; Wang, L.S.; et al. Cbx4 governs HIF-1 $\alpha$ to potentiate angiogenesis of hepatocellular carcinoma by its SUMO E3 ligase activity. Cancer Cell 2014, 25, 118-131. [CrossRef] [PubMed]

50. Guo, H.; Xu, J.; Zheng, Q.; He, J.; Zhou, W.; Wang, K.; Huang, X.; Fan, Q.; Ma, J.; Cheng, J.; et al. NRF2 SUMOylation promotes de novo serine synthesis and maintains HCC tumorigenesis. Cancer Lett. 2019, 466, 39-48. [CrossRef]

51. Peek, J.; Harvey, C.; Gray, D.; Rosenberg, D.; Kolla, L.; Levy-Myers, R.; Yin, R.; McMurry, J.L.; Kerscher, O. SUMO targeting of a stress-tolerant Ulp1 SUMO protease. PLoS ONE 2018, 13, e0191391. [CrossRef]

52. Tang, Z.; Li, C.; Kang, B.; Gao, G.; Li, C.; Zhang, Z. GEPIA: A web server for cancer and normal gene expression profiling and interactive analyses. Nucleic Acids Res. 2017, 45, W98-W102. [CrossRef] [PubMed]

53. Liu, X.; Liu, J.; Xiao, W.; Zeng, Q.; Bo, H.; Zhu, Y.; Gong, L.; He, D.; Xing, X.; Li, R.; et al. SIRT1 Regulates N(6) -Methyladenosine RNA Modification in Hepatocarcinogenesis by Inducing RANBP2-Dependent FTO SUMOylation. Hepatology 2020, 72, 2029-2050. [CrossRef]

54. Xi, R.; Kadur Lakshminarasimha Murthy, P.; Tung, K.L.; Guy, C.D.; Wan, J.; Li, F.; Wang, Z.; Li, X.; Varanko, A.; Rakhilin, N.; et al. SENP3-mediated host defense response contains HBV replication and restoRes. protein synthesis. PLoS ONE 2019, 14, e0209179. [CrossRef] [PubMed]

55. Deng, R.; Zhao, X.; Qu, Y.; Chen, C.; Zhu, C.; Zhang, H.; Yuan, H.; Jin, H.; Liu, X.; Wang, Y.; et al. Shp2 SUMOylation promotes ERK activation and hepatocellular carcinoma development. Oncotarget 2015, 6, 9355-9369. [CrossRef]

56. Yang, S.T.; Yen, C.J.; Lai, C.H.; Lin, Y.J.; Chang, K.C.; Lee, J.C.; Liu, Y.W.; Chang-Liao, P.Y.; Hsu, L.S.; Chang, W.C.; et al. SUMOylated CPAP is required for IKK-mediated NF- $\kappa$ B activation and enhances HBx-induced NF- $\kappa$ B signaling in HCC. J. Hepatol. 2013, 58, 1157-1164. [CrossRef] [PubMed]

57. Xu, H.; Wang, H.; Zhao, W.; Fu, S.; Li, Y.; Ni, W.; Xin, Y.; Li, W.; Yang, C.; Bai, Y.; et al. SUMO1 modification of methyltransferaselike 3 promotes tumor progression via regulating Snail mRNA homeostasis in hepatocellular carcinoma. Theranostics 2020, 10, 5671-5686. [CrossRef]

58. Liu, J.; Sha, M.; Wang, Q.; Ma, Y.; Geng, X.; Gao, Y.; Feng, L.; Shen, Y.; Shen, Y. Small ubiquitin-related modifier $2 / 3$ interacts with p65 and stabilizes it in the cytoplasm in HBV-associated hepatocellular carcinoma. BMC Cancer 2015, 15, 675. [CrossRef]

59. Jiang, Q.F.; Tian, Y.W.; Shen, Q.; Xue, H.Z.; Li, K. SENP2 regulated the stability of $\beta$-catenin through WWOX in hepatocellular carcinoma cell. Tumour Biol. 2014, 35, 9677-9682. [CrossRef]

60. Fang, S.; Qiu, J.; Wu, Z.; Bai, T.; Guo, W. Down-regulation of UBC9 increases the sensitivity of hepatocellular carcinoma to doxorubicin. Oncotarget 2017, 8, 49783-49795. [CrossRef]

61. Liu, J.; Tao, X.; Zhang, J.; Wang, P.; Sha, M.; Ma, Y.; Geng, X.; Feng, L.; Shen, Y.; Yu, Y.; et al. Small ubiquitin-related modifier 1 is involved in hepatocellular carcinoma progression via mediating p65 nuclear translocation. Oncotarget 2016, 7, 22206-22218. [CrossRef]

62. Jin, Z.L.; Pei, H.; Xu, Y.H.; Yu, J.; Deng, T. The SUMO-specific protease SENP5 controls DNA damage response and promotes tumorigenesis in hepatocellular carcinoma. Eur. Rev. Med. Pharmacol. Sci. 2016, 20, 3566-3573. 
63. Wu, M.; Lin, Z.; Li, X.; Xin, X.; An, J.; Zheng, Q.; Yang, Y.; Lu, D. HULC cooperates with MALAT1 to aggravate liver cancer stem cells growth through telomere repeat-binding factor 2. Sci. Rep. 2016, 6, 36045. [CrossRef]

64. Mei, L.; Yuan, L.; Shi, W.; Fan, S.; Tang, C.; Fan, X.; Yang, W.; Qian, Y.; Hussain, M.; Wu, X. SUMOylation of large tumor suppressor 1 at Lys751 attenuates its kinase activity and tumor-suppressor functions. Cancer Lett. 2017, 386, 1-11. [CrossRef] [PubMed]

65. Zubiete-Franco, I.; García-Rodríguez, J.L.; Lopitz-Otsoa, F.; Serrano-Macia, M.; Simon, J.; Fernández-Tussy, P.; Barbier-Torres, L.; Fernández-Ramos, D.; Gutiérrez-de-Juan, V.; López de Davalillo, S.; et al. SUMOylation regulates LKB1 localization and its oncogenic activity in liver cancer. EBioMedicine 2019, 40, 406-421. [CrossRef] [PubMed]

66. Qin, G.; Tu, X.; Li, H.; Cao, P.; Chen, X.; Song, J.; Han, H.; Li, Y.; Guo, B.; Yang, L.; et al. Long Noncoding RNA p53-Stabilizing and Activating RNA Promotes p53 Signaling by Inhibiting Heterogeneous Nuclear Ribonucleoprotein K deSUMOylation and Suppresses Hepatocellular Carcinoma. Hepatology 2020, 71, 112-129. [CrossRef] [PubMed]

67. Yen, C.J.; Yang, S.T.; Chen, R.Y.; Huang, W.; Chayama, K.; Lee, M.H.; Yang, S.J.; Lai, H.S.; Yen, H.Y.; Hsiao, Y.W.; et al. Hepatitis $B$ virus $X$ protein (HBx) enhances centrosomal P4.1-associated protein (CPAP) expression to promote hepatocarcinogenesis. J. BioMed. Sci. 2019, 26, 44. [CrossRef] [PubMed]

68. Morimoto, A.; Kannari, M.; Tsuchida, Y.; Sasaki, S.; Saito, C.; Matsuta, T.; Maeda, T.; Akiyama, M.; Nakamura, T.; Sakaguchi, M.; et al. An HNF4 $\alpha$-microRNA-194/192 signaling axis maintains hepatic cell function. J. Biol. Chem. 2017, 292, 10574-10585. [CrossRef]

69. Ge, H.; Du, J.; Xu, J.; Meng, X.; Tian, J.; Yang, J.; Liang, H. SUMOylation of HSP27 by small ubiquitin-like modifier $2 / 3$ promotes proliferation and invasion of hepatocellular carcinoma cells. Cancer Biol. Ther. 2017, 18, 552-559. [CrossRef]

70. Ha, H.L.; Kwon, T.; Bak, I.S.; Erikson, R.L.; Kim, B.Y.; Yu, D.Y. IGF-II induced by hepatitis B virus X protein regulates EMT via SUMO mediated loss of E-cadherin in mice. Oncotarget 2016, 7, 56944-56957. [CrossRef]

71. Lin, D.; Fu, Z.; Yang, G.; Gao, D.; Wang, T.; Liu, Z.; Li, G.; Wang, Y. Exportin-5 SUMOylation promotes hepatocellular carcinoma progression. Exp. Cell Res. 2020, 395, 112219. [CrossRef] [PubMed]

72. Jiang, Z.; Zhang, C.; Liu, X.; Ma, X.; Bian, X.; Xiao, X.; Gao, R.; Sun, Y.; Wu, W.; Zhao, P. Dexamethasone inhibits stemness maintenance and enhances chemosensitivity of hepatocellular carcinoma stem cells by inducing deSUMOylation of HIF- $1 \alpha$ and Oct4. Int. J. Oncol. 2020, 57, 780-790. [CrossRef]

73. Hou, P.P.; Luo, L.J.; Chen, H.Z.; Chen, Q.T.; Bian, X.L.; Wu, S.F.; Zhou, J.X.; Zhao, W.X.; Liu, J.M.; Wang, X.M.; et al. Ectosomal PKM2 Promotes HCC by Inducing Macrophage Differentiation and Remodeling the Tumor Microenvironment. Mol. Cell 2020, 78 , 1192-1206.e1110. [CrossRef]

74. Zhang, C.Y.; Jiang, Z.M.; Ma, X.F.; Li, Y.; Liu, X.Z.; Li, L.L.; Wu, W.H.; Wang, T. Saikosaponin-d Inhibits the Hepatoma Cells and Enhances Chemosensitivity Through SENP5-Dependent Inhibition of Gli1 SUMOylation Under Hypoxia. Front. Pharmacol. 2019, 10, 1039. [CrossRef] [PubMed]

75. Li, J.; Zhou, Y.; Liu, Y.; Dai, B.; Zhang, Y.H.; Zhang, P.F.; Shi, X.L. Sorafenib inhibits caspase-1 expression through suppressing TLR4/stat3/SUMO1 pathway in hepatocellular carcinoma. Cancer Biol. Ther. 2018, 19, 1057-1064. [CrossRef] [PubMed]

76. Qin, Y.; Bao, H.; Pan, Y.; Yin, M.; Liu, Y.; Wu, S.; Li, H. SUMOylation alterations are associated with multidrug resistance in hepatocellular carcinoma. Mol. Med. Rep. 2014, 9, 877-881. [CrossRef]

77. Kreß, J.K.C.; Jessen, C.; Marquardt, A.; Hufnagel, A.; Meierjohann, S. NRF2 Enables EGFR Signaling in Melanoma Cells. Int. J. Mol. Sci. 2021, 22, 3803. [CrossRef] [PubMed]

78. Jiménez-Villegas, J.; Ferraiuolo, L.; Mead, R.J.; Shaw, P.J.; Cuadrado, A.; Rojo, A.I. NRF2 as a therapeutic opportunity to impact in the molecular roadmap of ALS. Free Radic. Biol. Med. 2021, 173, 125-141. [CrossRef]

79. Barghout, S.H.; Schimmer, A.D. E1 Enzymes as Therapeutic Targets in Cancer. Pharmacol. Rev. 2021, 73, 1-58. [CrossRef]

80. Lv, X.; Yu, H.; Zhang, Q.; Huang, Q.; Hong, X.; Yu, T.; Lan, H.; Mei, C.; Zhang, W.; Luo, H.; et al. SRXN1 stimulates hepatocellular carcinoma tumorigenesis and metastasis through modulating ROS/p65/BTG2 signalling. J. Cell Mol. Med. 2020, 24, 10714-10729. [CrossRef]

81. Vigodner, M.; Morris, P.L. Testicular expression of small ubiquitin-related modifier-1 (SUMO-1) supports multiple roles in spermatogenesis: Silencing of sex chromosomes in spermatocytes, spermatid microtubule nucleation, and nuclear reshaping. Dev. Biol. 2005, 282, 480-492. [CrossRef]

82. Chen, B.; Liu, B.; Yu, T.; Han, Y.; Wu, C.; Wang, Z.Y. Nuclear Dbf2-related (NDR1) functions as tumor suppressor in glioblastoma by phosphorylation of Yes-associated protein (YAP). Chin. Med. J. 2021, 134, 2054-2065. [CrossRef] [PubMed]

83. Li, H. Intercellular crosstalk of liver sinusoidal endothelial cells in liver fibrosis, cirrhosis and hepatocellular carcinoma. Dig. Liver Dis. 2021. [CrossRef]

84. Meng, L.; Ma, R.; Yan, R.; Yuan, D.; Li, Y.; Shi, L.; Li, K. Profiles of immune infiltration in the tumor microenvironment of hepatocellular carcinoma. J. Gastrointest. Oncol. 2021, 12, 1152-1163. [CrossRef] [PubMed]

85. Cano, L.; Bertani, S.; Island, M.L.; Cerapio, J.P.; Ruiz, E.; Pineau, P.; Monbet, V.; Boudjema, K.; Taxa, L.; Casavilca-Zambrano, S.; et al. Metallomic profile in non-cirrhotic hepatocellular carcinoma supports a phenomenon of metal metabolism adaptation in tumor cells. Sci. Rep. 2021, 11, 14195. [CrossRef]

86. Yang, Y.; Mao, F.; Guo, L.; Shi, J.; Wu, M.; Cheng, S.; Guo, W. Tumor cells derived-extracellular vesicles transfer miR-3129 to promote hepatocellular carcinoma metastasis by targeting TXNIP. Dig. Liver Dis. 2021, 53, 474-485. [CrossRef]

87. Zeng, Z.; Lu, Q.; Liu, Y.; Zhao, J.; Zhang, Q.; Hu, L.; Shi, Z.; Tu, Y.; Xiao, Z.; Xu, Q.; et al. Effect of the Hypoxia Inducible Factor on Sorafenib Resistance of Hepatocellular Carcinoma. Front. Oncol. 2021, 11, 641522. [CrossRef] [PubMed] 
88. Fornari, F.; Giovannini, C.; Piscaglia, F.; Gramantieri, L. Elucidating the Molecular Basis of Sorafenib Resistance in HCC: Current Findings and Future Directions. J. Hepatocell Carcinoma 2021, 8, 741-757. [CrossRef]

89. Wang, F.; Sun, F.; Luo, J.; Yue, T.; Chen, L.; Zhou, H.; Zhang, J.; Yang, C.; Luo, X.; Zhou, Q.; et al. Loss of ubiquitin-conjugating enzyme E2 (Ubc9) in macrophages exacerbates multiple low-dose streptozotocin-induced diabetes by attenuating M2 macrophage polarization. Cell Death Dis. 2019, 10, 892. [CrossRef]

90. He, X.; Lai, Q.; Chen, C.; Li, N.; Sun, F.; Huang, W.; Zhang, S.; Yu, Q.; Yang, P.; Xiong, F.; et al. Both conditional ablation and overexpression of E2 SUMO-conjugating enzyme (UBC9) in mouse pancreatic beta cells result in impaired beta cell function. Diabetologia 2018, 61, 881-895. [CrossRef]

91. Xiong, R.; Wang, A. SCE1, the SUMO-conjugating enzyme in plants that interacts with NIb, the RNA-dependent RNA polymerase of Turnip mosaic virus, is required for viral infection. J. Virol. 2013, 87, 4704-4715. [CrossRef] [PubMed]

92. Xu, D.; Sun, F.; Bi, J.; Guan, Y.; Luo, X.; Chen, X.; Lv, Y.; Jin, Y. Effects of E2 binding enzyme UBC9 on porcine oocyte maturation, apoptosis and embryo development. Reprod. Domest. Anim. 2020, 55, 1526-1534. [CrossRef]

93. Floris, A.; Mazarei, M.; Yang, X.; Robinson, A.E.; Zhou, J.; Barberis, A.; D’Hallewin, G.; Azara, E.; Spissu, Y.; Iglesias-Ara, A.; et al. SUMOylation Protects FASN Against Proteasomal Degradation in Breast Cancer Cells Treated with Grape Leaf Extract. Biomolecules 2020, 10, 529. [CrossRef]

94. Bialik, P.; Woźniak, K. SUMO proteases as potential targets for cancer therapy. Postepy Hig. Med. Dosw. 2017, 71, 997-1004. [CrossRef]

95. Langston, S.P.; Grossman, S.; England, D.; Afroze, R.; Bence, N.; Bowman, D.; Bump, N.; Chau, R.; Chuang, B.C.; Claiborne, C.; et al. Discovery of TAK-981, a First-in-Class Inhibitor of SUMO-Activating Enzyme for the Treatment of Cancer. J. Med. Chem. 2021, 64, 2501-2520. [CrossRef] [PubMed]

96. Fukuda, I.; Ito, A.; Hirai, G.; Nishimura, S.; Kawasaki, H.; Saitoh, H.; Kimura, K.; Sodeoka, M.; Yoshida, M. Ginkgolic acid inhibits protein SUMOylation by blocking formation of the E1-SUMO intermediate. Chem. Biol. 2009, 16, 133-140. [CrossRef]

97. Borenstein, R.; Hanson, B.A.; Markosyan, R.M.; Gallo, E.S.; Narasipura, S.D.; Bhutta, M.; Shechter, O.; Lurain, N.S.; Cohen, F.S.; Al-Harthi, L.; et al. Ginkgolic acid inhibits fusion of enveloped viruses. Sci. Rep. 2020, 10, 4746. [CrossRef] [PubMed]

98. Fukuda, I.; Ito, A.; Uramoto, M.; Saitoh, H.; Kawasaki, H.; Osada, H.; Yoshida, M. Kerriamycin B inhibits protein SUMOylation. J. Antibiot. 2009, 62, 221-224. [CrossRef] [PubMed]

99. Ren, Q.; Zhang, C.Y.; Ma, X.F.; Cheng, R.Z.; Bian, X.Y.; Xiao, X.L.; Liu, X.Z.; Zhou, H.F. Spectomycin B1 induces VEGFR2 de-SUMO modification to inhibit angiogenesis in nasopharyngeal carcinoma. Lin Chung Er Bi Yan Hou Tou Jing Wai Ke Za Zhi 2019, 33, 1181-1184. [CrossRef]

100. Huang, W.; He, T.; Chai, C.; Yang, Y.; Zheng, Y.; Zhou, P.; Qiao, X.; Zhang, B.; Liu, Z.; Wang, J.; et al. Triptolide inhibits the proliferation of prostate cancer cells and down-regulates SUMO-specific protease 1 expression. PLoS ONE 2012, 7, e37693. [CrossRef]

101. Wu, J.; Lei, H.; Zhang, J.; Chen, X.; Tang, C.; Wang, W.; Xu, H.; Xiao, W.; Gu, W.; Wu, Y. Momordin Ic, a new natural SENP1 inhibitor, inhibits prostate cancer cell proliferation. Oncotarget 2016, 7, 58995-59005. [CrossRef] [PubMed]

102. Liu, K.; Wang, X.; Li, D.; Xu, D.; Li, D.; Lv, Z.; Zhao, D.; Chu, W.F.; Wang, X.F. Ginkgolic Acid, a SUMO-1 Inhibitor, Inhibits the Progression of Oral Squamous Cell Carcinoma by Alleviating SUMOylation of SMAD4. Mol. Ther. Oncolytics 2020, 16, 86-99. [CrossRef] [PubMed] 